\title{
JOINT STOCK COMPANY BODIES AS A LEGAL INSTRUMENT FOR THE IMPLEMENTATION OF ITS ECONOMIC COMPETENCE
}

\section{Harahonych O. V.}

\section{INTRODUCTION}

The issue of the proper legal regulation of the economic competence relation realization by the entities of economic law acting in the organizational and legal form of a joint stock company (hereinafter referred to as JSC) comes to the fore in the conditions of reforming the socioeconomic system of Ukraine. In the process of updating corporate legislation, the issues associated with the implementation of the JSC's economic competence through the system of authorized bodies come to the focus of legal science and practice. This, in turn, requires appropriate research from the standpoint of economic and legal science.

JSC is an economic organization whose realization of economic competence has certain features determined by the complex system of interests of corporate relation subjects (JSC, shareholders, officials of JSC bodies, etc.), which should be taken into account in the process of the company's activity. In this regard, in order to ensure the effective economic activity of the joint stock company, as well as the balance of influence and balance of interests of corporate relations participants, the legislator enshrines an array of necessary legal means and instruments to the legal mechanism of economic competence realization.

The main legal instrument used by JSCs to exercise their economic competence in the field of management is the bodies of commercial organizations. Thus, the JSC participates in the economic turnover through its bodies, which implement the economic rights established by the legislation and the company charter and ensure the fulfillment of the economic responsibilities assigned to it.

\section{The concept and features of joint stock company bodies}

Despite the crucial importance of the JSC bodies in the legal mechanism of its economic competence realization, the analysis of economic legislation elucidates its imperfection in the regulation of these issues. First of all, it is predetermined by the fact that there is no legal definition of the concept of a JSC body and its legal nature is not explicitly defined.

Thus, the domestic legislator defines the concept of the JSC body rather vaguely, without specifying at the same time neither its meaning nor the legal status of the bodies. 
The question of the legal nature of joint stock company bodies has repeatedly been the subject of research by scholars since pre-revolutionary times till the present times. However, a unanimous theoretical position on this issue has not been adopted in terms of theory.

The research of the legal nature of JSC bodies, in our opinion, should be done through the analysis of the features inherent in such bodies. Therewith, it should be borne in mind that the definition of the JSC body's features is closely related to the properties of the JSC body as a business organization, which in accordance with Part 5 of Art. 55 of the Economic Code of Ukraine (hereinafter - the EC of Ukraine) has the status of a legal entity ${ }^{1}$. Therefore, it is expedient to analyze the JSC body's features in the light of scientific developments, including the study of the features of the legal entity bodies. The analysis of the economic legislation norms, as well as the research on the given issue, gives grounds to highlight the following basic features of the JSC body.

Firstly, the JSC body is an organizationally segregated, structured part of the company as a business organization.

The JSC body is a part of the company and not an independent entity of commercial law. On the one hand, such part is organizationally separated from other parts of the business organization (other bodies, separate units of the JSC, etc.). On the other hand, the body is a structured part of the joint stock company, which enables it to function in the corporate management system of the company. For instance, the structure of a collegial body usually includes the chairman and members of the JSC body.

Secondly, the JSC body is formed in accordance with the procedure established by law and the company charter.

According to par. 2 Part 1 of Article 92 of the Civil Code of Ukraine (hereinafter referred to as the CC of Ukraine), the procedure for the establishment of legal entity bodies shall be governed by the constituent documents and the law ${ }^{2}$.

The general procedure for the formation of the joint stock company bodies is determined by the norms of the Law of Ukraine "On Joint Stock Companies" (hereinafter - the Law on JSC). At the stage of a joint stock company foundation, the question of formation of company bodies and their personal composition in accordance with par. 4, 6 of part 2, article 10 of the Law on JSC is decided at the joint stock company foundation meeting. In the course of the JSC's activities, the powers to form the bodies of a company are within the competence of the general meeting of shareholders

${ }^{1}$ Господарський кодекс України від 16 січня 2003 року. Відомості Верховної Ради України. 2003. № 18. Ст. 144.

${ }^{2}$ Цивільний кодекс України від 16 січня 2003 року. Офіиійний вісник Украӥни. 2003. № 11. Ст. 461. 
(par. 17-19, 21, 26 part 2 of Article 33 of the Law on JSC) and the supervisory board (point 8, 10 part 2 of Article 52 of the Law on JSC) ${ }^{3}$.

The creation of a body is always preconditioned by the existence of appropriate provisions in the internal memorandum of a legal entity, without regard to the specific substrate of such body ${ }^{4}$. In this regard, the general procedure for the formation of bodies established at the level of the Law on JSC is specified in the JSC statutory and internal documents of the company.

Thirdly, the JSC body consists of natural persons related to the company by corporate relations and having the status of officials (except for the participants of the JSC general meeting).

According to par. 15 of part 1 of Article 2 of the Law on Joint Stock Companies, officers of joint stock company's bodies are the natural persons who occupy the posts of the chairman and members of the supervisory board, executive body, audit commission of a joint stock company, a corporate secretary as well as the chairman and members of another company's body if establishment of such a body is stipulated by the company charter. Thus, the legislator determines that the body of the joint stock company may include only natural persons. The general meeting of shareholders is no exception to this rule.

This feature of the body is foreordained by the fact that management as a type of intellectual activity, as a certain product of intelligence in general, is the process and result of decision-making, respectively, management as such can be carried out only by a person, an individual ${ }^{5}$.

Fourth, the body is endowed with a set of powers, the realization of which is carried out within the limits of JSC's own economic competence.

These powers allow the body to pursue certain actions in resolving the issues of the internal organization of the legal entity and its representation in external relations, while realizing the will of the legal entity itself, and thereby acquiring rights and assuming responsibilities on its behalf ${ }^{6}$.

As long as the JSC body operates within the limits of the powers defined by law and the company charter, its actions are presumed to be the actions of the joint stock company itself as a business organization. However, when an officer of a JSC body starts acting outside these powers, his/her actions shall be considered as the actions of such an individual as an independent entity and not the actions of the JSC. In case the company incurs losses caused to

\footnotetext{
${ }^{3}$ Про акціонерні товариства: Закон України від 17 вересня 2008 року № 514-VI. Відомості Верховної Ради Украӥни. 2008. № 50-51. Ст. 384.

${ }^{4}$ Федосеев С. В. К проблеме правосубъектности органов управления акционерным обществом. Законодательство. 2010. № 7. С. 36.

${ }^{5}$ Тычинская Е. В. Договор о реализации функций единоличного исполнительного органа хозяйственного общества. Москва : Статут, 2012. С. 38.

${ }^{6}$ Могилевский С. Д. Органы управления хозяйственными обществами: правовой аспект : монография. Москва : Дело, 2001. С. 104-123.
} 
the company by their actions (omission), an officer of the public company's bodies shall assume economic and legal liability in the form of damages in conformity with the law (par. 2, part 2 of Article 89 of the CC of Ukraine, part 8 of Article 53, part 2 of Article 63 of the Law on JSC).

This approach of the legislator is fully in line with the provisions of the First Council Directive 68/151/EEC of 9 March 1968 "On co-ordination of safeguards which, for the protection of the interests of members and others, are required by Member States of companies within the meaning of the second par. of Article 58 of the Treaty, with a view to making such safeguards equivalent throughout the Community”. Thus, according to par. 1, 2 of Article 9 of the First Council Directive, acts done by the organs of the company shall be binding upon it even if those acts are not within the objects of the company, unless such acts exceed the powers that the law confers or allows to be conferred on those organs ${ }^{7}$.

Fifth, the JSC body is separated from specific natural persons who constitute it at a certain moment.

The body of a legal person is an abstraction, behind which there is always a certain human substrate, beyond which the body cannot express the will of the legal person. At the same time, having some dependence on the human substrate, the body does not have a strong attachment to specific people, since all members of the management bodies change periodically, which does not affect the existence of the organ as a whole ${ }^{8}$.

The body should not be identified with the specific individuals forming it at the moment, since the fact of the staff change does not affect the validity of legally significant actions previously performed by the JSC through its body ${ }^{9}$.

Sixth, the body actions in the implementation of the JSC's economic competence in external relations are the actions of the company.

The actions of the bodies should be understood as the actions of the legal entity itself, and the bodies themselves - as a statutory legal fiction, designed to regulate the internal structure of the legal entity, to assign certain powers to its certain part (competence) ${ }^{10}$. As a matter of fact, when a citizen (a group

${ }^{7}$ First Council Directive 68/151/EEC of 9 March 1968 on co-ordination of safeguards which, for the protection of the interests of members and others, are required by Member States of companies within the meaning of the second paragraph of Article 58 of the Treaty, with a view to making such safeguards equivalent throughout the Community. Official Journal L. 065. 14. 03. 1968. P. 8.

${ }^{8}$ Федосеев С. В. К проблеме правосубъектности органов управления акционерным обществом. Законодательство. 2010. № 7. С. 33-34.

9 Ломакин Д. В. Общие положения об органах акционерного общества. Вестник МГУ. Серия 11. Право. 2003. № 4. С. 28.

${ }^{10}$ Корпоративное право. Актуальные проблемы теории и практики / под общ. ред. В. А. Белова. Москва : Юрайт, 2014. С. 28. 
of citizens), constituting its body, exercises the legal personality of a legal entity, the entity itself has the legal personality ${ }^{11}$.

This feature of the JSC body is taken into account in court practice in the resolution of corporate disputes. Thus, the economic procedural legislation does not provide for the possibility of appealing to the commercial court with a complaint about the actions or inaction of the JSC bodies. Instead, a person whose rights have been violated by the actions or omissions of the JSC body is not deprived of the right to go to court with a claim of a company responsibility to pursue certain actions or refrain from committing such actions. Therefore, according to par. 2.7 of the Plenary assembly resolution of the Supreme Economic Court of Ukraine "On issues of resolving disputes arising from relationships of a corporate nature”, the defendant in disputes on the invalidation of the decision of the general meeting and other management bodies of the legal entity is the legal entity itself ${ }^{12}$.

Seventh, the JSC's will as a business entity is formed and realized through the bodies.

The will of a legal entity is formed by the natural persons who make up the body of a legal entity by exercising certain powers, i.e. by means of pursuing actions ${ }^{13}$. Through the body, the will of a legal entity is formed or manifested in accordance with the rights and responsibilities available to it, as provided by law, other legal acts and the charter. Expressing the will of the legal entity and representing its interests in the relations with other persons, the body does not become a direct party to such legal relations, and is not recognized as an independent subject of law ${ }^{14}$.

There is no sufficient reason to claim that a body of a legal entity is an independent subject of law in both external and internal corporate relations since it cannot act outside the legal entity; the body of a legal entity forms the will only of a legal entity, but in nowise its own; the body of a legal entity does not have its own subjective rights and responsibilities, but acts only within the powers conferred on it by the legal entity; it cannot be held responsible for its actions on its own since the actions of the body are recognized by the actions of the legal entity itself ${ }^{15}$.

${ }^{11}$ Гелецька I. О. Правове регулювання відносин представництва у цивільному праві: дис... канд. юрид. наук : 12.00.03. Київ, 2005. С. 68-69.

${ }^{12}$ Про деякі питання практики вирішення спорів, що виникають 3 корпоративних правовідносин: постанова Пленуму Вищого господарського суду України від 25 лютого 2016 року № 4. Вісник господарського судочинства. 2016. № 1.

${ }^{13}$ Вилкин С. С. Гражданско-правовая природа волевых актов коллегиальных органов юридического лица : автореф. дис ... канд. юрид. наук. 12.00.03. Москва, 2009. С. 8-9.

14 Ломакин Д. В. Общие положения об органах акционерного общества. Вестник МГУ. Серия 11. Право. 2003. № 4. С. 27-29.

${ }^{15}$ Федосеев С. В. К проблеме правосубъектности органов управления акционерным обществом. Законодательство. 2010. № 7. С. 36. 
Eighth, the economic competence, which is vested in the company, is distributed among the JSC's bodies.

The company competence is a statute established by law, other legal acts and constituent documents of the company, subject of activity of the company body, as well as specific powers necessary for the company body to perform its functions and the tasks assigned to it $^{16}$.

The activity of any legal entity would be chaotic since in the absence of a distinct competence division between the internal parts (not to mention the complete absence (isolation) of any internal parts), the process of forming the will, as well as its expression (bringing it to all third parties) would be contradictory and inconsistent, which would ultimately lead to the impossibility of any activity at all ${ }^{17}$.

In turn, the JSC governing bodies are a clearly structured system in which each of the units is endowed with a special, unique power in the sphere of the JSC's volition. The will of the JSC is formed directly in each of the governing bodies of the company but only on issues that fall within the competence of these bodies ${ }^{18}$.

The analysis of features that are inherent in the bodies of JSC allows defining the concept of JSC body.

A JSC body can be defined as an organizationally separated and structured part of JSC being an economic organization, formed in the order stipulated by the law and the company charter consisting of individuals, endowed with a set of powers necessary for the realization of the JSC's economic competence, and through which the JSC's will as a business entity is formed and / or exercised.

\section{The system of JSC's bodies}

The JSC's economic competence is not implemented by any separate body but through a system of bodies.

In general, the system of JSC bodies includes a supreme body, a supervisory board, an executive body, an audit commission and other bodies in accordance with the legislature.

The implementation of the JSC's economic competence by each of the above bodies has its own peculiarities, determined by the nature, purpose, and its place in the system of the company bodies.

The general meeting of the joint stock is recognized as the company supreme body, which in accordance with part 1 of Article 32 and part 1

\footnotetext{
${ }^{16}$ Ломакин Д. В. Корпоративные правоотношения: общая теория и практика ее применения в хозяйственных обществах. Москва : Статут, 2008. С. 302.

${ }^{17}$ Корпоративное право. Актуальные проблемы теории и практики / под общ. ред. В. А. Белова. Москва : Юрайт, 2014. С. 28.

18 Эбзеев Б. Б. Участие акционерных обществ в гражданском обороте : дис. ... канд. юрид. наук : 12.00.03. Москва, 2001. С. 95.
} 
of Article 33 of the Law on the JSC may decide any issues of operation of a joint stock company except for those which fall within the exclusive competence of other bodies of the company by law.

An important feature of the general meeting in the implementation of the economic competence of JSC is their position as a will-forming body. Within the limits of their competence, the general meeting reaches decisions that are a fixed expression of a legal entity's will. Only the general meeting can determine the legal fate of a legal entity: to exist in such a form or to cease its activity due to inappropriateness ${ }^{19}$. It is the general meeting of JSC that creates the basic legal basis for the activities of other bodies of the company $^{20}$. Thus, according to par. 9 of part 2 of Article 33 of the Law on JSC, the approval of the provisions on the company bodies falls within the competence of the company supreme body.

The legal status of the JSC general meeting has been repeatedly the subject of our research in the legal literature ${ }^{21}$. The conducted research gives the basis to conclude that although the JSC general meeting has the maximum scope of powers and is the most representative body of the company, the expression of the JSC's will in the exercise of its economic competence through direct contact with other participants of economic relations by the legislator rests with other bodies of the company, basically, the executive body.

The JSC supervisory board is the company supervisory body, which according to part 1 of Article 51 of the Law on JSC, provides protection of the interests of the company shareholders and controls and regulates the operation of the executive body within the authority specified by the company charter and the Law on JSC.

In JSC realizing banking activities, this body may also be named "bank's council” or "bank's supervisory board" (part 3 of Article 37 of the Law of Ukraine "On Banks and Banking”"22). In the company having 9 or fewer

\footnotetext{
${ }^{19}$ Корпоративные отношения: комплексне проблемы теоретического изучения и нормативно-правового регулирования : монография / отв. ред. Е. Д. Тягай. Москва : Норма: ИНФРА-М, 2014. С. 95.

${ }^{20}$ Спасибо-Фатєєва I. В. Цивільно-правові проблеми акціонерних правовідносин : автореф. дис. ... д-ра юрид. наук : 12.00.03. Харків, 2000. С. 17.

${ }^{21}$ Гарагонич О. В. Загальні збори у системі корпоративного управління акціонерного товариства. Экономико-правовые исследования в XXI веке: общие проблемь хозяйственного права на современном этапе развития общества: Материалы Десятой международной научно-практической интернет-конференции (г. Донецк, 21-30 сентября 2012 года). Донецк: Ноулидж, 2013. С. 59-71; Гарагонич О. В. Скликання позачергових загальних зборів акціонерного товариства 3 ініціативи акціонерів. Науковий вісник УжНУ. Серія Право. 2012. Випуск 19. Том 2. С. 171-176; Корпоративне право: навчальний посібник / за заг. ред. О. В. Гарагонича, С. М. Грудницької. Київ : Видавничий Дім «Слово», 2014. С. 160-164, 182-207; Корпоративне право : навчальний посібник / за заг. ред. О. В. Гарагонича, С. М. Грудницької, Л. М. Дорошенко. 2-е вид., випр. і доп. Київ : Видавничий дім «АртЕк», 2018. С. 167-172, 192-222.

${ }^{22}$ Про банки і банківську діяльність: Закон України від 07 грудня 2000 року № 2121-ІІІ. Відомості Верховної Ради України. 2001. № 5м6. Ст. 30.
} 
shareholders - owners of common shares its powers shall be exercised by a general meeting if there is no supervisory board there (part 2 of Article 51 of the Law on JSC). Therefore, a supervisory board shall not be mandatory in the system of bodies of such joint stock companies.

The orientation of the will is a characteristic feature of the willpower formation in which the supervisory board is involved. The will created by the supervisory board is directed primarily at the executive body and not at third parties outside the corporate relations ${ }^{23}$. This is due to the fact that the presence of a supervisory board in the system of JSC bodies should promote the balance of interests in the company since this weakens the position of the executive body ${ }^{24}$. Therefore, a member of the supervisory board shall not be simultaneously a member of the executive body and/or a member of the audit commission (inspector) of this company (part 2 of Article 53 of the Law on JSC).

The analysis of issues referred to in part 2 of Article 2 of the Law on Joint Stock Company to the competence of the Supervisory Board, gives grounds to conclude that the Supervisory Board is the body of management of the general competence performing the general management of the company in the period between the general meetings ${ }^{25}$.

Nevertheless, we do not agree with the suggestion put forward in the legal literature that the regulation of the supervisory board of the management should not settle the issues of the company's economic activity $^{26}$. Contradictory to the executive body that manages the current JSC's activities, the supervisory board carries out the company's "strategic management" 27 . By exercising strategic management, the supervisory board controls the adherence of the executive body to the elaborated strategy for the implementation of the JSC's economic competence and, if necessary, regulates the activities of the executive body.

The executive body is the body that manages the company's current operations. The executive body of the JSC must be formed in a mandatory manner. The implementation of the JSC's economic competence in the relations with other participants in the sphere of management is performed primarily through the executive body. According to parts 1 and 3 of Article 58

\footnotetext{
${ }^{23}$ Корпоративные отношения: комплексне проблемы теоретического изучения и нормативно-правового регулирования : монография / отв. ред. Е. Д. Тягай. Москва : Норма: ИНФРА-М, 2014. С. 100.

24 Долинская В. В. Общее собрание акционеров : монография. Москва : Норма: ИНФРА-М, 2016. С. 19.

${ }^{25}$ Корпоративне право: навчальний посібник / за заг. ред. О. В. Гарагонича, С. М. Грудницької. Київ : Видавничий Дім «Слово», 2014. С. 170.

${ }^{26}$ Артеменко С. В. Цивільно-правові проблеми управління акціонерним товариством : автореф. дис. ... канд. юрид. наук : 12.00.03. Київ, 2004. С. 12.

${ }_{27}$ Осипенко О. В. Акционерное общество. Корпоративные процедуры. Книга первая: Общее собрание и совет директоров. Москва : Статут, 2009. С. 296.
} 
of the Law on JSC, the public company executive body may be collegial (management board, directorate) or sole (director, director-general).

The Constitutional Court of Ukraine in its resolution of January 12, 2010 № 1-rp / 2010 emphasizes that the authority of the executive body shall include settlement of all issues associated with management of day-to-day operations of the company except for the matters falling within the exclusive competence of the general meeting and the supervisory board.

In realising the management activity, the executive body implements the collective will of the members of the company who are the bearers of corporate rights ${ }^{28}$. Therefore, the executive body is a managing body that implements the economic competence of the joint stock company, expressing the will of the company in the relations with other entities of commercial law.

Contrary to the supreme body and the supervisory board, the powers of the JSC executive body to exercise the company's economic competence are not specified in the Law on JSC. The legislator provides the possibility of detailing such powers by the company itself in its charter and / or in the regulation on the executive body (part 4 of Article 57 of the Civil Code of Ukraine, part 5 of Article 58 of the Law on JSC).

The controlling body of the joint stock company is the audit commission (auditor), which in accordance with part 1 of Article 73 of the Law on JSC shall conduct an inspection of the financial and economic activity of a joint stock company. Joint stock companies with up to 100 shareholders - owners of common shares of the company, shall introduce the post of an auditor (or select an audit committee) and in the companies with over 100 shareholders - owners of common shares of the company, must set up an audit commission.

In exercising the JSC's economic competence, the participation of the controlling body in the formation of the company's will is limited to the right to put forward proposals to the agenda of the JSC general meeting and to require the convening of an extraordinary general meeting, as well as the possibility of members of the audit commission (auditor) to attend the general meeting and participate in the agenda discussion with the right of advisory vote.

In our opinion, the inclusion of an audit commission (auditor) in the system of JSC bodies is not justified at the present stage. In practice, the audit commission usually follows the instructions of the supervisory board and the executive body and does not ensure the objectivity of the audit outcome of the JSC's financial and economic activity.

In addition, according to Article 56 of the Law on JSC, the supervisory board may, and in some cases is required, to form an audit commission from

\footnotetext{
${ }^{28}$ Рішення Конституційного Суду України № 1-рп/2010 від 12 січня 2010 року «У справі за конституційним зверненням товариства $з$ обмеженою відповідальністю «Міжнародний фінансово-правовий консалтинг» про офіційне тлумачення частини третьої статті 99 Цивільного кодексу України». Офіиійний вісник України. 2010. № 3. Ст. 113.
} 
among its members. In this case, the performance of the audit functions of the JSC's financial and economic activities will be duplicated. In this regard, we consider it sufficient to carry out the audit of the JSC's financial and economic activity using an audit commission and exclude the audit commission (auditor) from the system of JSC bodies.

Other bodies are bodies of joint stock companies, whose formation is enshrined in the company charter in accordance with par. 15 of part 1 of Article 2 of the Law on JSC. Such bodies may include termination commission (par. 1 of part 6 of Article 83 of the Law on JSC), reorganization commission (part 3 of Article 105 of the CC of Ukraine), liquidation commission (part 4 of Article 88 of the Law on JSC), the liquidator (part 3 of Article 105 of the CC of Ukraine). The formation of these bodies is related to the decision by the JSC supreme body to terminate the company.

According to part 4 of Article 105 of the CC of Ukraine, the termination commission (reorganization commission, liquidation commission) or liquidator assume the powers over the management of joint stock company, including powers for realization of the company's economic competence from the moment of their appointment. Since this change of the bodies used to exercise the JSC's economic competence may affect the interests of other participants of economic relations in accordance with par. 26 of part 2 of Article 9 of the Law of Ukraine "On State Registration of Legal Entities, Individual Entrepreneurs and Public Formations", the information on the termination commission (liquidator, liquidation commission, etc.) should be entered into the Unified State Registry (USR) ${ }^{29}$.

Contrary to the supreme, supervisory, executive and controlling bodies, which operate throughout the JSC's existence, the termination commission (reorganization commission, liquidation commission) or the liquidator belong to temporary bodies that perform the functions of realizing the company's economic competence only during the period of the termination procedure (reorganization or liquidation) of the JSC.

Analysing the issues of formation and activity of "the JSC other bodies", we consider it groundless to refer to the company bodies the so-called "auxiliary bodies" including the tellers, the general meeting presidium, the supervisory board office, etc. as described in the legal literature ${ }^{30}$. From a legal point of view, such "auxiliary bodies" do not participate in the implementation of the JSC's economic competence, but only perform the functions of the technical support in the work of the JSC bodies: collecting ballots during voting, preparing the premises for meetings of the relevant body, etc.

\footnotetext{
${ }^{29}$ Про державну реєстрацію юридичних осіб, фізичних осіб-підприємців та громадських формувань: Закон України від 15 травня 2003 року № 755-IV. Офічиійний вісник України. 2003. № 25. Ст. 1172.

${ }^{30}$ Могилевский С. Д. Органы управления хозяйственными обществами: правовой аспект : монография. Москва : Дело, 2001. С. 135.
}

80 
The legal regulation of the issues of the JSC's economic competence implementation through the system of bodies is based not only on imperative but also on dispositive principles. This explains the fact that the order of implementation by the JSCs of economic competence in two different JSCs can differ significantly depending on certain circumstances (number of shareholders, presence / absence of the supervisory board, type of executive body, etc.).

The dispositive nature is inherent in a number of provisions of the Law on JSC, which regulates the procedure for the implementation of the JSC's economic competence through the system of authorized bodies.

Thus, according to par. 14 of part 2 of Article 13 of the Law on JSC, the composition of the company's management bodies and their competence, the method of the formation of these bodies, of electing and recalling their members, of passing their decisions, and the procedure of changing the composition of the company's bodies and their competence are set out in the charter of a Joint Stock Company.

The legislator also provides the JSC with the opportunity to resolve the issue of the distribution of powers to exercise economic competence between its bodies in the company's charter.

In the distribution of powers between JSC bodies in the charter, the socalled "residual principle" is applied ${ }^{31}$. Thus, the issues falling within the exclusive competence of the general meeting cannot be resolved by the supervisory board (except in cases provided for by law). Similarly, the executive body is empowered to address matters which not within the exclusive competence of the general meeting and the supervisory board.

In addition, in certain cases, the Law on JSC provides for the possibility of redistribution of powers between the JSC bodies in the course of the company activity by amending the articles in the company's charter. For instance, according to par. 8 of part 2 of Article 52 of the Law on JSC, the election and revocation of the powers of the chairman of the executive body is within the competence of the supervisory board. However, par. 1, part 5 of Article 59 of the Law on JSC envisages that the election of the executive body chairman may be within the competence of the general meeting of shareholders.

This approach of the legislator allows the JSC to build its own management system for the implementation of its economic competence. At the same time, the system enshrined in the Law on JSC envisages the establishment of internal organizational legal relations which ensure the necessary interaction between the bodies of the company and the possibility of realization of the JSC's economic competence in the economic sphere.

\footnotetext{
${ }^{31}$ Могилевский С. Д. Органы управления хозяйственными обществами: правовой аспект : монография. Москва : Дело, 2001. С. 135.
} 
In our opinion, one of the directions of further development of the legislation of Ukraine on the implementation of the JSC's economic competence on a dispositive basis may be the introduction of a legal mechanism for transferring the authority of the JSC executive body to another business organization (the managing company).

The essence of this mechanism is limited to the fact that, according to the JSC supreme body's decision, the execution of the executive body's authority is performed by another business organization, called the management company. It is suggested that the management company shall execute the powers of the executive body based on the contract concluded with the joint stock company.

The introduction of a legal mechanism for transferring the powers of the JSC executive body to another business organization (management company), in our opinion, will increase the attractiveness of the organizational form of the joint stock company for domestic and foreign investors, who fear to lose control over the activities of the company in which they have made the investment for the acquisition of shares. This mechanism may also be of interest to transnational corporations and large groups of companies whose management is objectively unable to delegate their representatives to the executive body of each controlled entity.

Some elements of the mechanism of transferring of the JSC executive body's powers to other business organizations have already been introduced by the domestic legislator in the field of joint investment. In particular, this mechanism applies to JSCs, the sole type of economic activity of which is joint venture activity, and which operate in the form of corporate funds.

In our opinion, in order to increase the efficiency of the JSC's economic competence implementation, it is advisable to allow the use of a delegation mechanism of the executive body's powers to the management company for all JSCs and not only corporate funds. Undoubtedly, this will require corresponding amendments to the Law on Joint Stock Company, Civil Code of Ukraine and other normative legal acts.

In order to introduce a legal mechanism for transferring the powers of the JSC executive body to another business organization (management company), it is suggested to amend Article 58-1 of the Law on JSC as follows:

"Article 58-1. Transfer of powers of the joint stock company's executive body to the management company.

1. By decision of the general meeting of shareholders, the powers of the a joint stock company's executive body may be delegated to another business organization (management company), except in cases provided by the law or the company charter.

2. The management company to which the powers of the joint stock company's executive body have been delegated shall manage the current activity of the company in the manner specified by the contract concluded 
between the joint stock company and the management company. The contract is signed by a person authorized by the general meeting of shareholders on behalf of the joint stock company. The agreement on the transfer of powers of the joint stock company's executive body to the management company is subject to state registration. Information on the conclusion of such an agreement shall be entered into the Unified State Register.

3. The executive body in the company shall not formed during the management company's execution of powers to manage the current activities of the joint stock company, unless otherwise provided by the agreement on the transfer of powers of the joint stock company's executive body to the management company.

4. The agreement on the transfer of powers of the joint stock company's executive body to the management company may be terminated at the decision of the general meeting of shareholders or the joint stock company's supervisory board at any time and for any reason".

This mechanism can be further extended to other organizational and legal forms of business organizations.

\section{CONCLUSIONS}

The conducted analysis gives grounds to draw the following conclusions.

A JSC body is an organizationally separated and structured part of JSC being an economic organization, formed in accordance with the procedure stipulated by the law and the company charter consisting of individuals, endowed with a set of powers necessary for the realization of the JSC's economic competence, and through which the JSC's will as a business entity is formed and / or exercised.

The features of JSC body include:

- the JSC body is an organizationally segregated, structured part of the JSC as a business organization;

- the JSC body is formed in accordance with the procedure established by law and the company charter;

- the JSC body consists of natural persons related to the company by corporate relations and having the status of officials (except for the participants of the JSC general meeting);

- the body is endowed with a set of powers, the realization of which is carried out within the limits of JSC's own economic competence;

- the JSC body is separated from specific natural persons who constitute it at a certain moment;

- the body actions in the implementation of the JSC's economic competence in external relations are the actions of the company;

- the JSC's will as a business entity is formed and realized through the bodies; 
- the economic competence, which is vested in the company, is distributed among the JSC's bodies.

The JSC's economic competence is not implemented by any separate body, but through a system of bodies including a supreme body, a supervisory board, an executive body, an audit commission and other bodies. The implementation of the JSC's economic competence by each of the above bodies has its own peculiarities, determined by the nature, purpose, and its place in the system of the company bodies.

The inclusion of an audit commission (auditor) in the system of JSC bodies is not justified at the present stage. It is advisable to review the JSC's financial and economic activity using the audit commission established by the supervisory board. In this regard, we suggest excluding the audit commission (auditor) from the system of JSC bodies.

In our opinion, one of the further development directions of the Ukrainian legislation on the implementation of the JSC's economic competence through the system of authorized bodies should be the introduction of a legal mechanism for delegating the authority of the JSC executive body to another business organization (the managing company).

\section{SUMMARY}

The article is devoted to the research of the issue of using the JSC bodies as a legal instrument for the realization of its economic competence. Analysing the legal nature of the joint stock company bodies, the author considers the main features of these bodies. Based on the performed research, the author elaborates his own definition of the concept of "joint stock company bodies".

The issues of joint stock companies' economic competence realization through the system of authorized bodies are thoroughly researched. The author substantiates his own vision of the role and place of each body of a joint stock company in the implementation of economic competence. The article suggests the directions of further development of the Ukrainian legislation on the realization of a joint stock company's economic competence through the system of authorized bodies. In particular, the necessity to exclude the audit commission (auditor) from the system of a joint stock company bodies is substantiated. Introducing a legal mechanism for the transfer of powers of a joint stock company's executive body to another business organization (the management company) is also suggested.

\section{REFERENCES}

1. First Council Directive 68/151/EEC of 9 March 1968 on coordination of safeguards which, for the protection of the interests of members and others, are required by Member States of companies within the meaning of the second paragraph of Article 58 of the Treaty, with a view to making 
such safeguards equivalent throughout the Community. Official Journal L. 065. 14. 03. 1968. P. 8.

2. Артеменко С. В. Цивільно-правові проблеми управління акціонерним товариством : автореф. дис... канд. юрид. наук : 12.00.03. Київ, 2004. 20 с.

3. Вилкин С. С. Гражданско-правовая природа волевых актов коллегиальных органов юридического лица : автореф. дис ... канд. юрид. наук. 12.00.03. Москва, 2009. 31 с.

4. Гарагонич О. В. Загальні збори у системі корпоративного управління акціонерного товариства. Экономико-правовые исследования в XXI веке: общие проблемы хозяйственного права на современном этапе развития общества: Материалы Десятой международной научно-практической интернет-конференции (г. Донецк, 2-30 сентября 2012 года). Донецк: Ноулидж, 2013. С. 59-71.

5. Гарагонич О. В. Скликання позачергових загальних зборів акціонерного товариства 3 ініціативи акціонерів. Науковий вісник УжНУ. Серія Право. 2012. Випуск 19. Том 2. С. 171-176.

6. Гелецька I. О. Правове регулювання відносин представництва у цивільному праві: дис... канд. юрид. наук : 12.00.03. Київ, 2005. 205 с.

7. Господарський кодекс України від 16 січня 2003 року. Відомості Верховної Ради України. 2003. № 18. Ст. 144.

8. Долинская В. В. Общее собрание акционеров : монография. Москва : Норма: ИНФРА-М, 2016. 160 с.

9. Корпоративне право : навчальний посібник / за заг. ред. О. В. Гарагонича, С. М. Грудницької, Л. М. Дорошенко. 2-е вид., випр. і доп. Київ : Видавничий дім «АртЕк», 2018. 400 с.

10. Корпоративне право: навчальний посібник / за заг. ред. О. В. Гарагонича, С. М. Грудницької. Київ : Видавничий Дім «Слово», 2014. 344 с.

11. Корпоративное право. Актуальные проблемы теории и практики / под общ. ред. В. А. Белова. Москва : Юрайт, 2014. 678 с.

12. Корпоративные отношения: комплексне проблемы теоретического изучения и нормативно-правового регулирования : монография / отв. ред. Е. Д. Тягай. Москва : Норма: ИНФРА-М, 2014. 144 с.

13. Ломакин Д. В. Общие положения об органах акционерного общества. Вестник МГУ. Серия 11. Право. 2003. № 4. С. 27-29.

14. Ломакин Д. В. Корпоративные правоотношения: общая теория и практика ее применения в хозяйственных обществах. Москва : Статут, 2008. 512 c.

15. Могилевский С. Д. Органы управления хозяйственными обществами: правовой аспект : монография. Москва : Дело, 2001. 360 с.

16. Осипенко О. В. Акционерное общество. Корпоративные процедуры. Книга первая: Общее собрание и совет директоров. Москва : Статут, 2009. 503 c. 
17. Про акціонерні товариства: Закон України від 17 вересня 2008 року № 514-VI. Відомості Верховної Ради Украӥни. 2008. № 50-51. Ст. 384.

18. Про банки і банківську діяльність: Закон України від 07 грудня 2000 року № 2121-III. Відомості Верховної Ради Украӥни. 2001. № 5-6. Ст. 30.

19. Про державну реєстрацію юридичних осіб, фізичних осіб-підприємців та громадських формувань: Закон України від 15 травня 2003 року № 755-IV. Офіиійний вісник України. 2003. № 25. Ст. 1172.

20. Про деякі питання практики вирішення спорів, що виникають 3 корпоративних правовідносин: постанова Пленуму Вищого господарського суду України від 25 лютого 2016 року № 4. Вісник господарського судочинства. 2016. № 1.

21. Рішення Конституційного Суду України № 1-рп/2010 від 12 січня 2010 року «У справі за конституційним зверненням товариства 3 обмеженою відповідальністю «Міжнародний фінансово-правовий консултинг» про офіційне тлумачення частини третьої статті 99 Цивільного кодексу України». Офіційний вісник Украӥни. 2010. № 3. Ст. 113.

22. Тычинская Е. В. Договор о реализации функций единоличного исполнительного органа хозяйственного общества. Москва : Статут, 2012. $175 \mathrm{c}$.

23. Федосеев С. В. К проблеме правосубъектности органов управления акционерным обществом. Законодательство. 2010. № 7. С. 29-38.

24. Цивільний кодекс України від 16 січня 2003 року. Офіиійний вісник Украӥни. 2003. № 11. Ст. 461.

25. Эбзеев Б. Б. Участие акционерных обществ в гражданском обороте : дис. ... канд. юрид. наук : 12.00.03. Москва, 2001. 249 с.

\section{Information about the author:} Harahonych O. V.,

$\mathrm{PhD}$ in Law, Associate Professor, Professor at the Department of Civil Law and Procedure,

Academy of Advocacy of Ukraine 27, Shevchenka blvd., Kyiv, 01032, Ukraine 